\title{
A Molecular Trefoil Knot From a Trimeric Circular Helicate
}

DOI:

10.1021/jacs.8b00738

\section{Document Version}

Accepted author manuscript

Link to publication record in Manchester Research Explorer

\section{Citation for published version (APA):}

Zhang, L., August, D., Zhong, J., Whitehead, G., Vitorica-Yrezabal, I., \& Leigh, D. (2018). A Molecular Trefoil Knot From a Trimeric Circular Helicate. American Chemical Society. Journal . https://doi.org/10.1021/jacs.8b00738

\section{Published in:}

American Chemical Society. Journal

\section{Citing this paper}

Please note that where the full-text provided on Manchester Research Explorer is the Author Accepted Manuscript or Proof version this may differ from the final Published version. If citing, it is advised that you check and use the publisher's definitive version.

\section{General rights}

Copyright and moral rights for the publications made accessible in the Research Explorer are retained by the authors and/or other copyright owners and it is a condition of accessing publications that users recognise and abide by the legal requirements associated with these rights.

\section{Takedown policy}

If you believe that this document breaches copyright please refer to the University of Manchester's Takedown Procedures [http://man.ac.uk/04Y6Bo] or contact uml.scholarlycommunications@manchester.ac.uk providing relevant details, so we can investigate your claim.

\section{OPEN ACCESS}




\title{
A Molecular Trefoil Knot From a Trimeric Circular Helicate
}

\author{
Liang Zhang, David P. August, Jiankang Zhong, George F. S. Whitehead, Iñigo J. Vitorica-Yrezabal \\ and David A. Leigh*
}

School of Chemistry, University of Manchester, Manchester M13 9PL, UK.

\section{Supporting Information Placeholder}

ABSTRACT: We report the two-step synthesis of a molecular trefoil knot in $90 \%$ overall yield through the self-assembly of a twelve-component trimeric circular zinc helicate followed by ring closing metathesis of six pendant alkene chains. Both the trimeric circular helicate intermediate and the resulting trefoil knot were characterized by NMR spectroscopy, mass spectrometry and Xray crystallography.

Knots are a structural feature of some proteins, circular DNA and spontaneously form in any polymer of sufficient length and flexibility. ${ }^{1}$ There are thousands of possible prime and composite knot topologies with 12 or fewer crossings, ${ }^{2}$ but to date chemists have reported designed synthetic routes to just three. ${ }^{\text {la }}$ Smallmolecule knots have been isolated as unexpected reaction products $^{3}$ or have been synthesized using complex intermediates, ${ }^{4-6}$ often involving lengthy syntheses, ${ }^{4}$ to generate the necessary crossings and direct strand assembly with the correct connectivity. Previous designed syntheses of small-molecule trefoil knots $\mathrm{s}^{4,5}$ (three crossings, the simplest nontrivial knot) were based on the connection of the distant termini of double-stranded linear metal helicates, ${ }^{4 a, c, e, f}$ the macrocyclization of single strands ${ }^{4 \mathrm{~d}, \mathrm{~g}, \mathrm{~h}, \mathrm{i}, \mathrm{sc}}$ (entangled through passive $e^{4 \mathrm{~g}, \mathrm{~h}}$ or active $\mathrm{e}^{4 \mathrm{i}}$ template synthesis), or lanthanide template ${ }^{5,7}$ synthesis. Attempts to extend these strategies to the synthesis of other knots have thus far proved unsuccessful. ${ }^{8}$ However, multi-metal-ion circular helicates (also termed 'cyclohelicates') have proved to be effective scaffolds for the assembly of a variety of topologically complex molecules with 4-8 crossings. ${ }^{1 \mathrm{a}, 6}$ Here we report on a highly efficient two-step synthesis of a trefoil knot based on a trimeric circular zinc helicate (Scheme $1)$.
Scheme 1. Synthesis of molecular trefoil knot 4 through a trimeric circular helicate. The intermediate helicate scaffold, 3, is shown as its X-ray crystal structure ${ }^{a}$

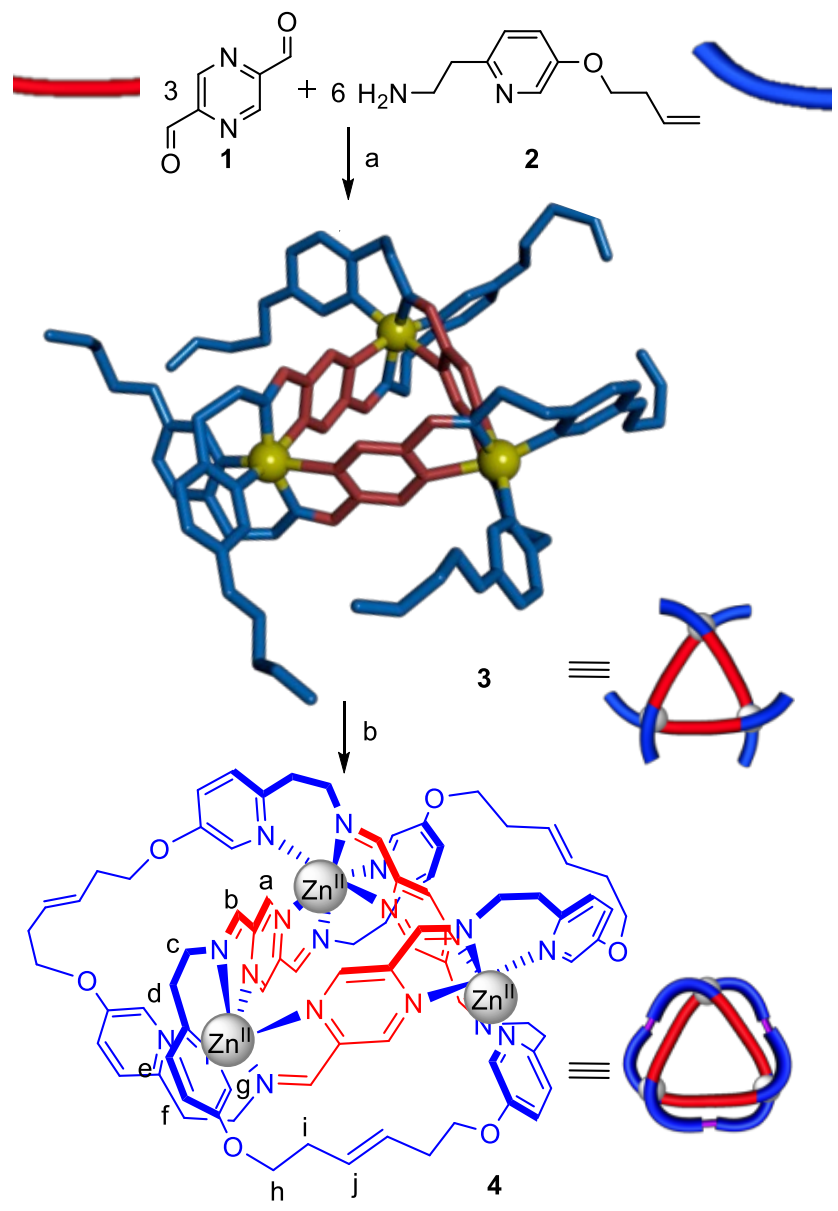

${ }^{a}$ Reagents and conditions: (a) $\mathrm{Zn}\left(\mathrm{BF}_{4}\right)_{2} \cdot \mathrm{H}_{2} \mathrm{O}$, acetonitrile, $60{ }^{\circ} \mathrm{C}$, $24 \mathrm{~h}, 90 \%$; (b) Hoveyda-Grubbs second generation catalyst, ${ }^{12}$ 1,2-dichloroethane/nitromethane $(1: 1), 60^{\circ} \mathrm{C}, 24 \mathrm{~h}$, quantitative.

The scaffold for the knot is based on the recent discovery ${ }^{9}$ by the Garden, Brooker, Larsen and Hanan groups of a rare exam$\mathrm{ple}^{10}$ of a trimeric circular helicate, assembled from pyrazine-2,5dicarbaldehyde (1), 2-(2-aminoethyl)pyridine and $\mathrm{Zn}$ (II) or Fe(II) tetrafluoroborates. In these systems the three metal ions position the ligand strands so that they pass over and under each other in a manner reminiscent of the crossings in the reduced representa- 
tion $^{1 \mathrm{a}}$ of a trefoil knot. We envisaged that extending the 2-(2aminoethyl)pyridine unit with a judiciously sited chain of suitable length could enable the entwined ligands to be joined with the connectivity required for a knot. Molecular modelling suggested that a 4-atom chain attached to the 5-position of the pyridine building block, i.e. 2 , should provide the positioning and orientation to promote joining of the ligands with the correct connectivity. The chain ends with an alkene so that the ligands can be fused through ring-closing olefin metathesis (RCM).

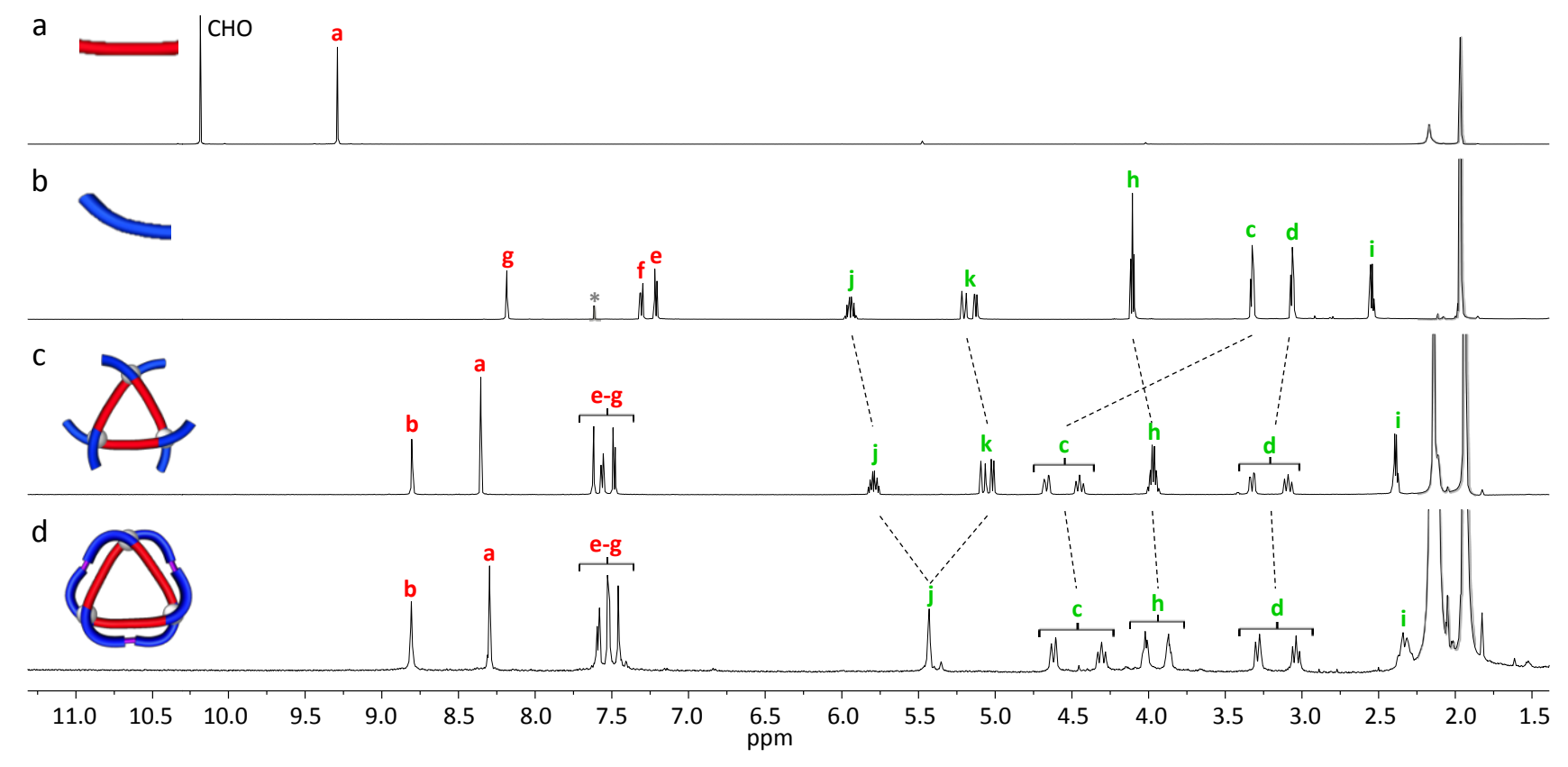

Figure 1. Partial ${ }^{1} \mathrm{H}$ NMR spectra (600 MHz, $298 \mathrm{~K}, \mathrm{CD}_{3} \mathrm{CN}$ ) of (a) bis-aldehyde 1; (b) amine 2; (c) trimeric cyclic helicate 3; (d) trefoil knot 4. The signal assignments correspond to the labelling shown in Scheme 1. ${ }^{*} \mathrm{CHCl}_{3}$.

Amine building block 2 was synthesized in four steps from commercially available 2-(5-bromopyridin-2-yl)ethanamine (see Supporting Information). Reaction of $\mathbf{1 , 2}$ and $\mathrm{Zn}\left(\mathrm{BF}_{4}\right)_{2} \cdot \mathrm{H}_{2} \mathrm{O}$ in a $1: 2: 1$ ratio at $60{ }^{\circ} \mathrm{C}$ for 24 hours in $\mathrm{CH}_{3} \mathrm{CN}$ resulted in the formation of essentially a single product (3), as evidenced by ${ }^{1} \mathrm{H}$ NMR spectroscopy of the crude reaction mixture, which was isolated in $90 \%$ yield after work-up. The room temperature ${ }^{1} \mathrm{H}$ NMR spectrum in $\mathrm{CD}_{3} \mathrm{CN}$ (Figure 1c) shows 3 to be a highly symmetrical species. Proton $\mathrm{H}^{\mathrm{c}}$ is shifted to low field and $\mathrm{H}^{\mathrm{c}}$ and $\mathrm{H}^{\mathrm{d}}$ are both diastereotopic, consistent with a circular helicate (Figure 1c). The size of the circular helicate as a trimer was confirmed by electrospray ionization mass spectrometry (ESI-MS) (Supplementary Information, Figures S1 and S2), demonstrating that the derivatization of the 2-(2-aminoethyl)pyridine building block is not detrimental to its ability ${ }^{11}$ to form a helicate of the required size and topology. 


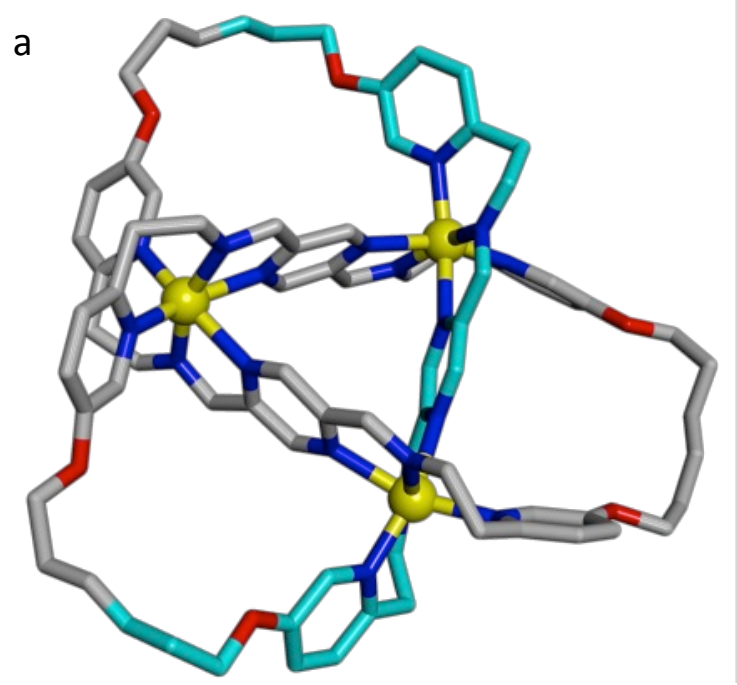

b

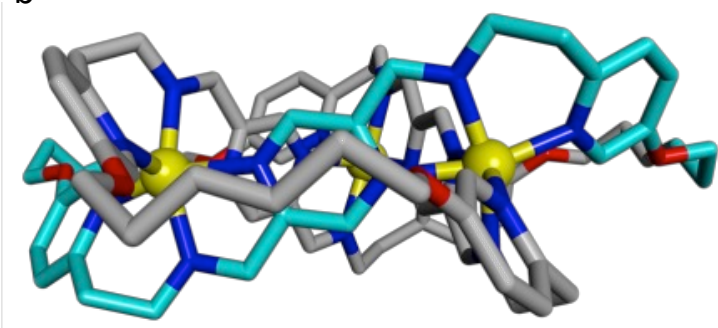

Figure 2. X-Ray crystal structure of trefoil knot 4. (a) top view; (b) side view. Hydrogen atoms and anions are omitted for clarity. Carbon atoms are shown in light grey except for one repeat unit of the chain which is colored turquoise; N, blue; $\mathrm{Zn}$, yellow; O, red. The crystallographic data and experimental details of the structural refinement of $\mathbf{3}$ and $\mathbf{4}$ are provided in the Supporting Information.

Slow diffusion of diethyl ether into a saturated acetonitrile solution of intermediate $\mathbf{3}$ afforded single crystals suitable for X-ray diffraction. The solid state structure (Scheme 1 and Supplementary Information Figure S5) confirms the trimeric circular helicate architecture with a $1: 1$ mixture of $\Lambda \Lambda \Lambda$ and $\Delta \Delta \Delta$ enantiomers in the unit cell. Each zinc metal has a distorted octahedral geometry and coordinates to six nitrogen atoms: two pyrazines, two pyridines and two amines. The $\mathrm{N}_{\mathrm{pz}}$ - $\mathrm{Zn}$ bonds (2.438(4)-2.332(3)) are significantly longer than the $\mathrm{N}_{\mathrm{py}} \mathrm{Zn}$ bonds (2.136(3)-2.078(4)) which provides the flexibility necessary to compress the $\mathrm{N}_{\mathrm{pz}}-\mathrm{Zn}$ $\mathrm{N}_{\mathrm{pz}}$ corner angles (82.6(1), 84.1(1), 83.5(1)) away from $90^{\circ}$. The deviation of the $\mathrm{N}_{\mathrm{pz}}-\mathrm{Zn}-\mathrm{N}_{\mathrm{pz}}$ corner angles and the $\mathrm{N}_{\mathrm{pz}}-\mathrm{Zn}-\mathrm{N}_{\mathrm{py}}$ pyrazine directional angle (165.2(1), 164.6(1), 162.5(1)) account for the formation of the trimeric circular helicate over linear or other sized circular helicates. ${ }^{9}$ The alkyl chains are well ordered in the solid state and are positioned such that joining each of them to their nearest neighbour would generate a trefoil knot.

Treatment of $\mathbf{3}$ with Hoveyda-Grubbs second generation catalyst $^{12}$ in a mixture of nitromethane and 1,2-dichloroethane at $60{ }^{\circ} \mathrm{C}$ for 24 hours, followed by precipitation with diethyl ether, afforded the corresponding trefoil knot $\mathbf{4}$ in quantitative yield (Scheme 1 and Supporting Information). The ${ }^{1} \mathrm{H}$ NMR spectrum of 4 (Figure 1d) confirmed the loss of the terminal alkene protons. The knot topology restricts the conformational freedom of the alkyl chains in $\mathbf{4}$ compared to $\mathbf{3}$, resulting in more pronounced separation of the diastereotopic $\mathrm{H}^{\mathrm{h}}$ protons. Single crystals of 4 suitable for X-ray diffraction were obtained by slow diffusion of diethyl ether into a saturated acetonitrile solution of the knot. The solid state structure confirmed the topology and symmetry of 4 (Figure 2). The 84-atom-long closed loop weaves a continuous path around the three zinc centers, with the strand crossing over or under itself at each zinc atom. Only $E$ olefins are present in the strand; the linkers are likely too short to accommodate $Z$ geometries in a low energy conformation that can still form the knot. All of the zinc atoms in $\mathbf{4}$ are in distorted octahedral geometries, as with the crystal structure of $\mathbf{3}$, but are more uniform due to the restraints conferred by the closed-loop knotted topology. The metal-ligand bond lengths are slightly shorter than those of the open trimeric circular helicate $3\left(\mathrm{~N}_{\mathrm{pz}}-\mathrm{Zn}\right.$ [average] 2.30 vs. 2.39; $\mathrm{N}_{\mathrm{py}} \mathrm{Zn}$ [average] $2.07 v$ s. 2.11), and the $\mathrm{N}_{\mathrm{pz}}-\mathrm{Zn}-\mathrm{N}_{\mathrm{pz}}$ corner angles are reduced from $83.4^{\circ}$ to $76.1^{\circ}$ to give a geometry for the three metal ions closer to an equilateral triangle. Both enantiomers $(\Lambda \Lambda \Lambda$ and $\Delta \Delta \Delta)$, in which the three zinc ions within one knot have the same configuration, are present in the unit cell in a $1: 1$ ratio.

The use of a trimeric circular helicate to simultaneously generate multiple crossings through error-checking dynamic imine formation, ${ }^{6 c, 13}$ together with covalent capture of the entwined architecture by ring closing metathesis, ${ }^{4 \mathrm{e}, 6 \mathrm{f}}$ enables the two-step synthesis of an 84-atom-loop molecular trefoil knot in $90 \%$ yield. It is one of the shortest and highest yielding designed routes to a trefoil knot developed to date. The simplicity and modular nature of the assembly process opens the way to the synthesis of more complex topologies in a manner that has not yet proved viable with previous trefoil knot strategies.

\section{ASSOCIATED CONTENT}

\section{Supporting Information}

The Supporting Information is available free of charge on the ACS Publications website.

Experimental procedures, analytic data $\left({ }^{1} \mathrm{H}\right.$ NMR, ${ }^{13} \mathrm{C}$ NMR, MS $)$ for all new compounds and crystallographic data of trimeric circular helicate 3 and trefoil knot 4. CCDC 1815058 and 1815059 contain the supplementary crystallographic data for this paper.

\section{AUTHOR INFORMATION}

\section{Corresponding Author}

*david.leigh@manchester.ac.uk

\section{Notes}

The authors declare no competing financial interests.

\section{ACKNOWLEDGMENTS}

We thank Dr Jonathan D. Danon for the preparation of compound 1 and Dr Jean-François Lemonnier and Dr Javier Jaramillo-Garcia for useful discussions. This work was supported by the Engineering and Physical Sciences Research Council (EPSRC). We are grateful for a President's Doctoral Scholarship (to LZ) and the China Scholarship Council for a studentship (to JZ). DAL is a Royal Society Research Professor.

\section{REFERENCES}

(1) (a) Fielden, S. D. P.; Leigh, D. A.; Woltering, S. Angew. Chem. Int. Ed. 2017, 56, 11166-11194. For other reviews on molecular knots, see: (b) Dietrich-Buchecker, C.; Colasson, B. X.; Sauvage, J.-P. Top. Curr. Chem. 2005, 249, 261-283. (c) Lukin, O.; Vögtle, F. Angew. Chem. Int Ed. 2005, 44, 1456-1477. (d) Fenlon, E. E. Eur. J. Org. Chem. 2008 5023-5035. (e) Beves, J. E.; Blight, B. A.; Campbell, C. J.; Leigh, D. A.; McBurney, R. T. Angew. Chem. Int. Ed. 2011, 50, 9260-9327. (f) Forgan, R. S.; Sauvage, J.-P.; Stoddart, J. F. Chem. Rev. 2011, 111, 5434-5464. (g) Amabilino, D. B.; Sauvage, J.-P. Top. Curr. Chem. 2012, 323, 107- 
126. (h) Ayme, J.-F.; Beves, J. E.; Campbell, C. J.; Leigh, D. A. Chem. Soc. Rev. 2013, 42, 1700-1712. (i) Lim, N. C. H.; Jackson, S. E. J. Phys.: Condens. Matter 2015, 27, 354101. (j) Horner, K. E.; Miller, M. A.; Steed, J. W.; Sutcliffe, P. M. Chem. Soc. Rev. 2016, 45, 6432-6448. (k) Sauvage, J.-P. Angew. Chem. Int. Ed. 2017, 56, 11080-11093.

(2) Adams, C. C. The knot book: an elementary introduction to the mathematical theory of knots; American Mathematical Society: Providence, RI, 2004.

(3) (a) Safarowsky, O.; Nieger, M.; Fröhlich, R.; Vögtle, F. Angew. Chem., Int. Ed. 2000, 39, 1616-1618. (b) Feigel, M.; Ladberg, R.; Engels, S.; Herbst-Irmer, R.; Fröhlich, R. Angew. Chem., Int. Ed. 2006, 45, 5698-5702. (c) Brüggemann, J.; Bitter, S.; Müller, S.; Müller, W. M.; Müller, U.; Maier, N. M.; Lindner, W.; Vögtle, F. Angew. Chem., Int. Ed. 2007, 46, 254-259. (d) Ponnuswamy, N.; Cougnon, F. B. L.; Clough, J. M.; Pantos, D. G.; Sanders, J. K. M. Science 2012, 338, 783-785. (e) Prakasam, T.; Lusi, M.; Elhabiri, M.; Platas-Iglesias, C.; Olsen, J.-C.; Asfari, Z.; Cianférani-Sanglier, S.; Debaene, F.; Charbonnière, L. J.; Trabolsi, A. Angew. Chem., Int. Ed. 2013, 52, 9956-9960. (f) Ponnuswamy, N.; Cougnon, F. B. L.; Pantoş, D. G.; Sanders, J. K. M. J. Am. Chem. Soc 2014, 136, 8243-8251. (g) Bilbeisi, R. A.; Prakasam, T.; Lusi, M.; El Khoury, R.; Platas-Iglesias, C.; Charbonnière, L. J.; Olsen, J.-C.; Elhabiri, M.; Trabolsi, A. Chem. Sci. 2016, 7, 2524-2531.

(4) (a) Dietrich-Buchecker, C. O.; Sauvage, J.-P. Angew. Chem. Int. Ed. 1989, 28, 189-192. (b) Dietrich-Buchecker, C. O.; Guilhem, J.; Pascard, C.; Sauvage, J.-P. Angew. Chem., Int. Ed. Engl. 1990, 29, 1154-1156. (c) Dietrich-Buchecker, C. O.; Sauvage, J.-P.; Kintzinger, J.-P.; Maltèse, P.; Pascard, C.; Guilhem, J. New J. Chem. 1992, 16, 931-942. (d) Ashton, P. R.; Matthews, O. A.; Menzer, S.; Raymo, F. M.; Spencer, N.; Stoddart, J. F.; Williams, D. J. Liebigs Ann./Recl. 1997, 2485-2494. (e) Rapenne, G.; Dietrich-Buchecker, C.; Sauvage, J.-P. J. Am. Chem. Soc. 1999, 121, 994-1001. (f) Dietrich-Buchecker, C.; Rapenne, G.; Sauvage, J.-P.; De Cian, A.; Fischer, J. Chem. Eur. J. 1999, 5, 1432-1439. (g) Adams, H.; Ashworth, E.; Breault, G. A.; Guo, J.; Hunter, C. A.; Mayers, P. C. Nature 2001, 411, 763. (h) Guo, J.; Mayers, P. C.; Breault, G. A.; Hunter, C. A Nat. Chem. 2010, 2, 218-220. (i) Barran, P. E.; Cole, H. L.; Goldup, S. M.; Leigh, D. A.; McGonigal, P. R.; Symes, M. D.; Wu, J. Y.; Zengerle, M. Angew. Chem., Int. Ed. 2011, 50, 12280-12284. For other synthetic strategies towards trefoil knots and the synthesis of related structures, see: (j) Schill, G.; Tafelmair, L. Synthesis 1971, 546-548. (k) Walba, D. M.; Armstrong, J. D.; Perry, A. E.; Richards, R. M.; Homan, T. C.; Haltiwanger, R. C. Tetrahedron 1986, 42, 1883-1894. (1) Fenlon, E. E.; Ito, B. R. Eur. J. Org. Chem. 2008, 3065-3068. (m) Bourlier, J.; Jouaiti, A.; Kyritsakas-Gruber, N.; Allouche, L.; Planeix, J.-M.; Hosseini, M. W. Chem. Commun. 2008, 6191-6193. (n) Arias, K. I.; Zysman-Colman, E.; Loren, J. C.; Linden, A.; Siegel, J. S. Chem. Commun. 2011, 47, 9588-9590. (o) Engelhard, D. M.; Freye, S.; Grohe, K.; John, M.; Clever, G. H. Angew. Chem., Int. Ed. 2012, 51, 4747-4750.

(5) (a) Ayme, J.-F.; Gil-Ramírez, G.; Leigh, D. A.; Lemonnier, J.-F.; Markevicius, A.; Muryn, C. A.; Zhang, G. J. Am. Chem. Soc. 2014, 136, 13142-13145. (b) Zhang, G.; Gil-Ramírez, G.; Markevicius, A.; Browne, C.; Vitorica-Yrezabal, I. J.; Leigh, D. A. J. Am. Chem. Soc. 2015, 137, 10437-10442. (c) Gil-Ramírez, G.; Hoekman, S.; Kitching, M. O.; Leigh, D. A.; Vitorica-Yrezabal, I. J.; Zhang, G. J. Am. Chem. Soc. 2016, 138, 13159-13162.

(6) (a) Beves, J. E.; Campbell, C. J.; Leigh, D. A.; Pritchard, R. G. Angew. Chem. Int. Ed. 2013, 52, 6464-6467. (b) Danon, J. J.; Krüger, A.; Leigh, D. A.; Lemonnier, J.-F.; Stephens, A. J.; Vitorica-Yrezabal, I. J.; Woltering, S. L. Science 2017, 355, 159-162. (c) Ayme, J.-F.; Beves, J. E.; Leigh, D. A.; McBurney, R. T.; Rissanen, K.; Schultz, D. Nat. Chem. 2012, 4, 15-20. (d) Ayme, J.-F.; Beves, J. E.; Leigh, D. A.; McBurney, R. T.; Rissanen, K.; Schultz, D. J. Am. Chem. Soc. 2012, 134, 9488-9497. (e) Ayme, J.-F.; Beves, J. E.; Campbell, C. J.; Gil-Ramírez, G.; Leigh, D. A.; Stephens, A. J. J. Am. Chem. Soc. 2015, 137, 9812-9815. (f) Marcos, V.; Stephens, A. J.; Jaramillo-Garcia, J.; Nussbaumer, A. L.; Woltering, S. L.; Valero, A.; Lemonnier, J.-F.; Vitorica-Yrezabal, I. J.; Leigh, D. A. Science 2016, 352, 1555-1559. (g) Leigh, D. A.; Pritchard, R. G.; Stephens, A. J. Nat. Chem. 2014, 6, 978-982. (h) Wood, C. S.; Ronson, T. K.; Belenguer, A. M.; Holstein, J. J.; Nitschke, J. R. Nat. Chem. 2015, 7, 354-358.

(7) For lanthanide template synthesis of other interlocked molecular architectures, see: (a) Zapata, F.; Blackburn, O. A.; Langton, M. J.; Faulkner, S.; Beer, P. D. Chem. Commun. 2013, 49, 8157-8159. (b) Langton, M. J.; Blackburn, O. A.; Lang, T.; Faulkner, S.; Beer, P. D. Angew. Chem. Int. Ed. 2014, 53, 11463-11466. (c) Lincheneau, C.; Jean-Denis, B.; Gunnlaugsson, T. Chem. Commun. 2014, 50, 2857-2860.
(8) Attempts to extend the linear helicate strategy beyond a Solomon link have thus far proved unsuccessful, see: Dietrich-Buchecker, C.; Colasson, B.; Jouvenot, D.; Sauvage, J.-P. Chem. Eur. J. 2005, 11, 4374-4386. (9) Hogue, R. W.; Dhers, S.; Hellyer, R. M.; Luo, J.; Hanan, G. S.; Larsen, D. S.; Garden, A. L.; Brooker, S. Chem. Eur. J. 2017, 23, 14193-14199.

(10) (a) Bark, T.; Duggeli, M.; Stoeckli-Evans, H.; von Zelewsky, A. Angew. Chem. Int. Ed. 2001, 40, 2848-2851. (b) Meng, W.; Ronson, T. K.; Clegg, J. K.; Nitschke, J. R. Angew. Chem. Int. Ed. 2013, 52, 1017 1021.

(11) Even modest changes to ligands can sometimes alter the topology (linear vs circular) and size of the resulting helicates. See, for example, Refs (6c), (6d) and Hasenknopf, B.; Lehn, J.-M.; Boumediene, N.; Dupont-Gervais, A.; Van Dorsselaer, A.; Kneisel, B.; Fenske, D. J. Am. Chem. Soc. 1997, 119, 10956-10962.

(12) (a) Garber, S. B.; Kingsbury, J. S.; Gray, B. L.; Hoveyda, A. H. $J$. Am. Chem. Soc. 2000, 122, 8168-8179; (b) Gessler, S.; Randl, S.; Blechert, S. Tetrahedron Lett. 2000, 41, 9973-9976.

(13) Corbett, P. T.; Leclaire, J.; Vial, L.; West, K. R.; Wietor, J.-L.; Sanders, J. K. M.; Otto, S. Chem. Rev. 2006, 106, 3652-3711.

\section{For Table of Contents (TOC)}




$$
=x \theta
$$

